University of Nebraska - Lincoln

DigitalCommons@University of Nebraska - Lincoln

Entomology Papers from Other Sources

Entomology Collections, Miscellaneous

1987

\title{
A Review of Perlinella Banks (Plecoptera: Perlidae)
}

Boris C. Kondratieff

Ralph F. Kirchner

Kenneth W. Stewart

Follow this and additional works at: https://digitalcommons.unl.edu/entomologyother

Part of the Entomology Commons

Kondratieff, Boris C.; Kirchner, Ralph F.; and Stewart, Kenneth W., "A Review of Perlinella Banks (Plecoptera: Perlidae)" (1987). Entomology Papers from Other Sources. 45.

https://digitalcommons.unl.edu/entomologyother/45

This Article is brought to you for free and open access by the Entomology Collections, Miscellaneous at DigitalCommons@University of Nebraska - Lincoln. It has been accepted for inclusion in Entomology Papers from Other Sources by an authorized administrator of DigitalCommons@University of Nebraska - Lincoln. 


\title{
A Review of Perlinella Banks (Plecoptera: Perlidae)
}

\author{
BORIS C. KONDRATIEFF, ${ }^{1}$ RALPH F. KIRCHNER, ${ }^{2,3}$ \\ AND KENNETH W. STEWART ${ }^{4}$
}

\begin{abstract}
Ann. Entomol. Soc. Am. 81(1): 19-27 (1988)
ABSTRACT The Nearctic stonefly genus Perlinella Banks is reviewed; three valid species are recognized. Perlinella drymo (Newman) and Perlinella ephyre (Newman) are widespread east of the Rocky Mountains, whereas Perlinella zwicki, n. sp. (P. fumipennis of Zwick 1971), is restricted to the southeastern Coastal Plain. Perlinella fumipennis (Walsh) is replaced as a synonym of Perlinella ephyre. Keys for adults and nymphs are provided, and the nymph of $P$. zwicki is described for the first time. Male drumming calls of Perlindella drymo and Perlinella ephyre are described.
\end{abstract}

KEY WORDS Insecta, Perlinella, taxonomy, drumming calls

THE GENus Perlinella was erected by Banks (1900) for Perla trivittata Banks, a species he described from Michigan in 1895. Needham \& Claassen (1925) regarded Perla elongata Walsh and $P$. trivittata as synonyms of Perlinella drymo (Newman), and Illies (1966) considered Perlinella a monotypic genus endemic to the Nearctic region. Zwick (1971) reviewed Perlinella, included Atoperla Banks as a new junior synonym, and recognized three rather widespread geographical species, $P$. drymo, $P$. (=Atoperla) ephyre (Newman), and P. (=Atoperla) fumipennis (Walsh). His revalidation of the name fumipennis for a species described originally from Illinois was based only on specimens from Florida. Because Hitchcock (1974) and Stark \& Gaufin (1976) have questioned Zwick's (1971) concept of $P$. fumipennis, we re-evaluate the status of the species included in Perlinella, and we provide descriptions of all life stages using current techniques in stonefly systematics.

Stewart \& Zeigler (1984b) discussed the use of stonefly drumming behavior as evidence for solving systematic questions and reconstructing phylogeny. One objective of our study was to include as much behavioral information as possible to help delineate Perlinella species and determine if they have a generically distinct drumming pattern.

\section{Materials and Methods}

Adult male and female terminalia were examined using the methods of Stark \& Szczytko (1981). Eggs were removed from gravid females and prepared for SEM, using the technique of Stark \& Szczytko (1981)

\footnotetext{
'Dep. of Entomology, Colorado State Univ., Fort Collins, CO 80523.

${ }^{2}$ The views of the author do not purport to reflect the position of the Department of the Army or the Department of Defense.

${ }^{3}$ U.S. Army Corps of Engineers, Huntington District, Water Quality Section, 502 8th Street, Huntington, WV 25701.

${ }^{4}$ Dep. of Biological Sciences, North Texas State Univ., Denton, TX 76203
}

The following museums, institutions, and individuals provided material for this study: R. W. Baumann, Brigham Young University; O. S. Flint, Jr., United States National Museum of Natural History; D. G. Huggins, State Biological Survey of Kansas; P. K. Lago, University of Mississippi; A. Provonsha, Purdue University; B. P. Stark, Mississippi College; J. D. Unzicker, Illinois Natural History Survey; C. Vogt, Museum of Comparative Zoology, Harvard University; and J. R. Voshell, Jr., Virginia Polytechnic Institute and State University.

Methods of recording and oscilloscope analysis of drumming followed Stewart \& Zeigler (1984a) and Maketon \& Stewart (1984). We attempted to rear nymphs of $P$. ephyre and $P$. zwicki for recording and comparison with signals of $P$. drymo (Zeigler \& Stewart 1977); however, suitable nymph populations of the two species were not found during the two years of the study, and a few P. ephyre rearings were unsuccessful. Recordings of male drumming calls $(n=27)$ were obtained from two wild males of $P$. ephyre collected from Arkansas, Stone County, Blanchard Springs, $2 \mathrm{mi} \mathrm{NE}$ of Hwy. 56, 19-III-1985, by B. C. Poulton.

\section{Perlinella Banks}

Perlinella Banks, 1900: 242. Type-species, Perla elongata $\mathrm{Walsh}=$ Perlinella drymo (Newman) (type by monotypy).

Atoperla Banks, 1905: 56 (syn. Zwick, 1971: 316).

Type species Perla producta Walsh = Atoperla ephyre (Newman) (type by monotypy).

Atoperla: Illies, 1966: 325.

Perlinella: Illies, 1966: 348; Zwick, 1973: 278; Stark \& Gaufin, 1976: 34.

Stark \& Gaufin (1976) provided a generic description of all life stages of Perlinella. Kirchner \& Kondratieff (1985) added the following two characters which help distinguish Perlinella nymphs from all other Nearctic Perlidae: 1) legs with a ventral and dorsal fringe of long silky hairs, and 

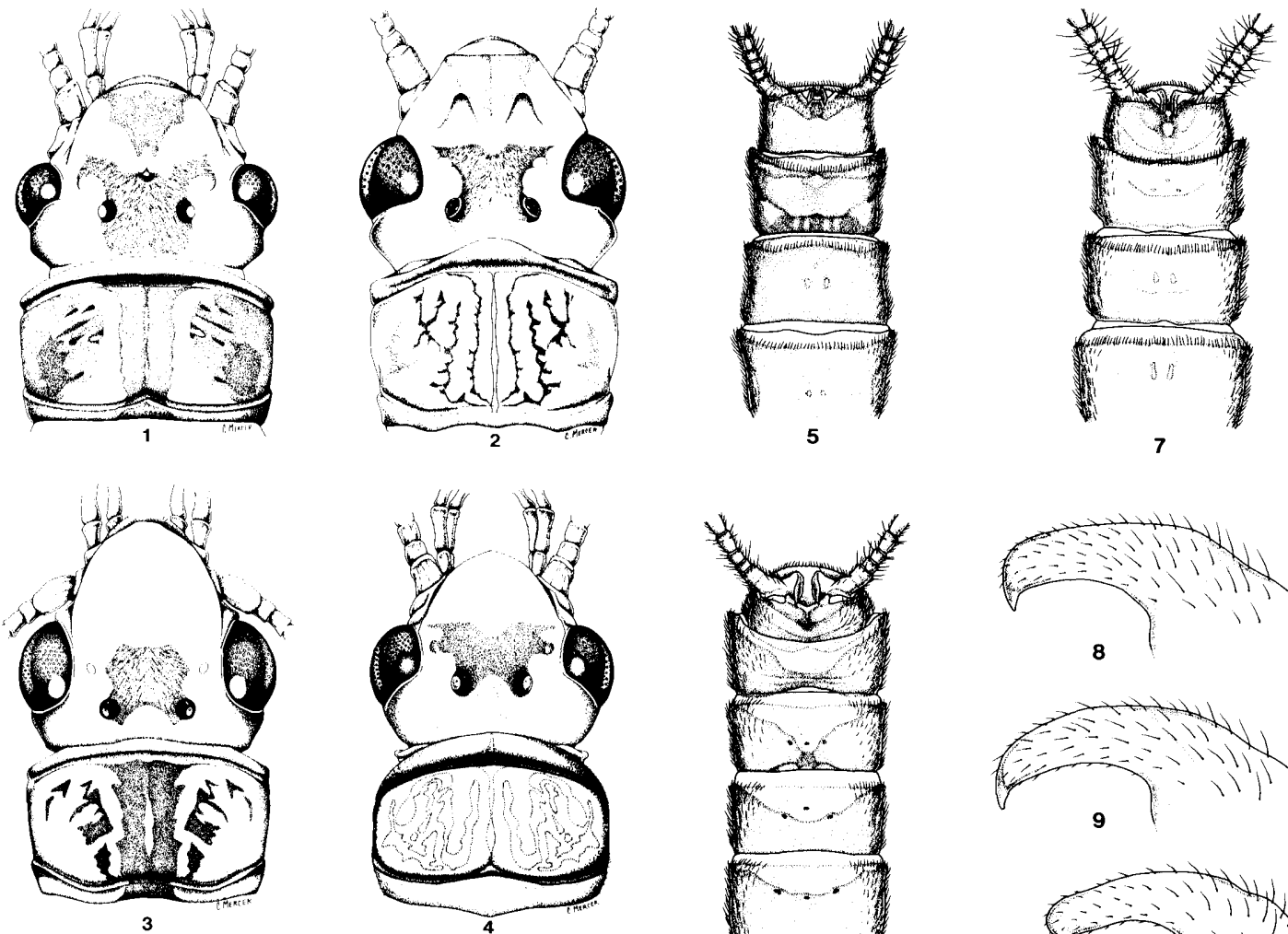

Fig. 1-4. Perlinella adult head and pronotum: (1) P. drymo, (2) P. ephyre, (3) P. ephyre, (4) P. zwicki.

2) mandibles with 4 teeth, right mandible with teeth $3 / 4$ subparallel (Fig. 23). Shepard \& Stewart (1983) illustrated the gills of the nymphs.

Adults are separated from other sympatric perlids by their distinct elongate habitus and in having one or more crossveins between $\mathrm{Al}$ and $\mathrm{A} 2$ of the forewings. Adult males are distinguished from other Nearctic Acroneuriini by the combination of 1) paired aedeagal sclerites, 2) large oval hammer on sternum 9, and 3) spinules present on tergum 10. Adult females are recognized by the short, bilobed subgenital plate.

Perlinella cinctipes Banks (1905) is a species of Perlesta (Needham \& Claassen 1925; B. Stark, personal communication).

\section{Keys to Species of Perlinella}

Males

1. A dark triangular spot in front of clypeus and pronotum with dark median stripe bordered by pale areas (Fig. 1); aedeagus as Fig. 11;3 ocelli ........ drymo (Newman)

Head with or without dark triangular spot in front of clypeus; pronotum without a distinct middorsal stripe (Fig. 2), or if with stripe, no dark triangular mark in front of clypeus (Fig. 3); aedeagi as Fig. 12 and 13; 2 ocelli

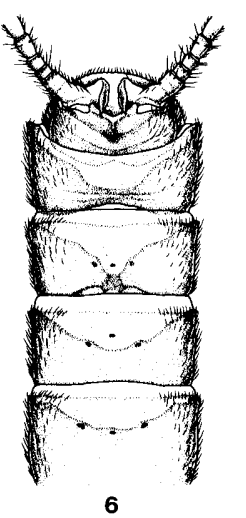

Fig. 5-10. Male terminalia, dorsal view: (5) P. drymo; (6) P. ephyre; (7) P. zwicki. Male paraproct, lateral view: (8) P. drymo; (9) P. ephyre; (10) P. zwicki.

2. Lateral sclerites of aedeagus with a sharp sclerotized hook (Fig. 12)

ephyre (Newman)

Lateral sclerite of aedeagus without a hook

(Fig. 13) . . zwicki Kondratieff et al., n. sp.

\section{Females}

1. Three ocelli; subgenital plate with broad median notch (Fig. 14) ... drymo (Newman)

Two ocelli; subgenital plate otherwise (Fig. 15 and 16 )

2. Subgenital plate truncately bilobed, usually strongly produced posteriorly, with deep medium notch (Fig. 15); head usually with dark pigmentation extending to clypeus (Fig. 2); distribution widespread east of Rocky Mountains .......ephyre (Newman)

Subgenital plate broadly bilobed, slightly produced posteriorly, median notch shallow (Fig. 16); head with dark pigmentation restricted to area between compound eyes, ending near anterior margin of compound eyes, clypeus yellow (Fig. 4); distribution southeastern U.S. $\ldots \ldots \ldots \ldots$ zwicki Kondratiefff et al., n. sp. 


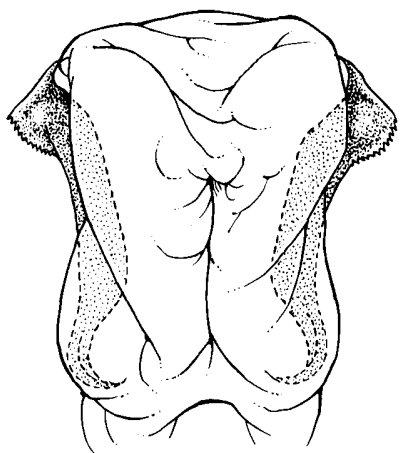

a

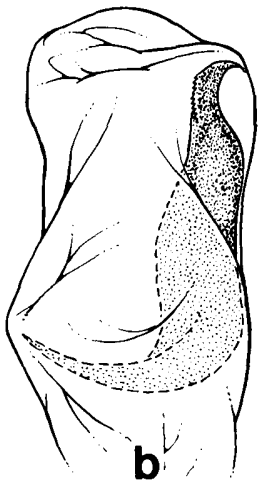

11
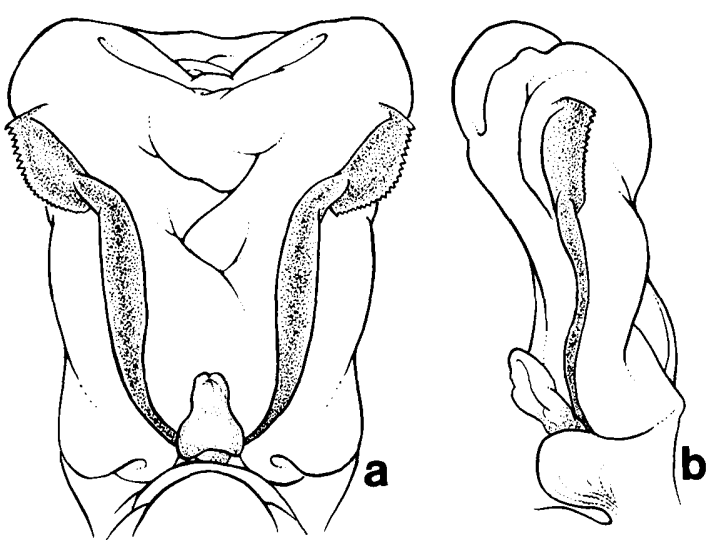

13
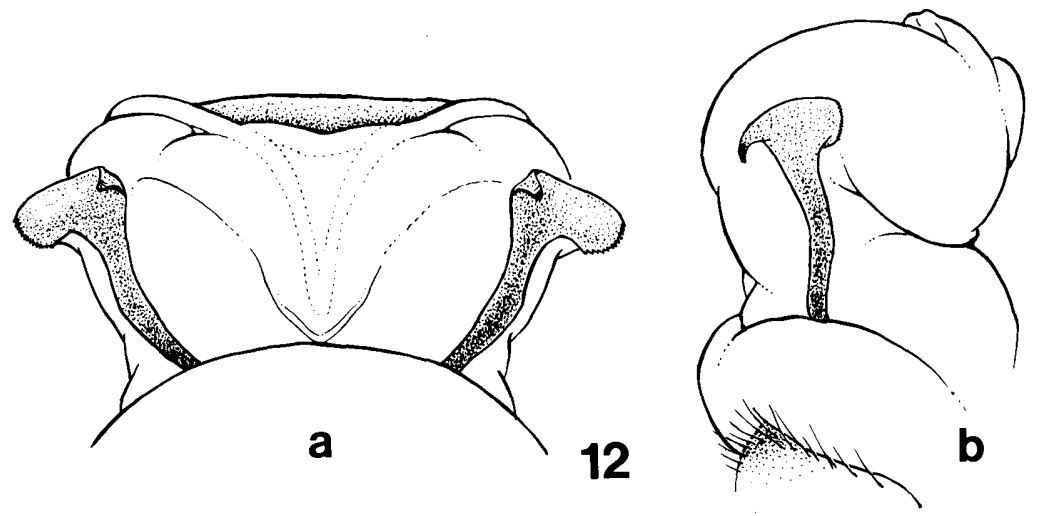

Fig. 11-13. Male aedeagus: (11) P. drymo, a, ventral view, b, laterial view; (12) P. ephyre, a, ventral view, b, lateral view; (13) $P$. zwicki, a, ventral view, b, lateral view.

tian Co., Taney Co., Oregon Co.; Mississippi ( $1 \hat{0}$, 1 §) Claiborne Co.; New York (2 \%, 2 N) Deer River; Ohio (1 \&) Athens Co.; Oklahoma (6 \$q) Murray Co.; Pennsylvania (1 \&) Northampton Co.; South Carolina (5 ỡ , 4 \&̊, $3 \mathrm{~N}$ ) Aiken Co.; Barnwell Co.; Saluda Co.; Texas (2 ở, 6 우, 4 N) McLennon Co.; Virginia (5 ổ, 9 \&̊, 2 N) Fairfax Co., Madison Co., Smyth Co.; West Virginia (4 \&\%) Hampshire Co.; Wisconsin (1 o) Washburn Co.; District of Columbia (1 \%).

\section{Perlinella ephyre (Newman)}

Fig. 2, 3, 6, 9, 12, 15, 19, 27

Chloroperla ephyre Newman, 1839: 87. Type locality, Georgia. Holotype female. Type in $\mathrm{BM}(\mathrm{NH})$, not examined.

Perla producta Walsh, 1862: 365. Type locality, Rock Island, Illinois (syn. Needham \& Claassen, 1925: 161). Type in MCZ (\#10130), examined.

Perla fumipennis Walsh, 1862: 366. Type locality, Rock Island, Illinois (syn. Needham \& Claassen, 1925: 161). Type lost. New Synonymy.
Atoperla consors Banks, 1948: 123. Type locality, Kingston, Rhode Island (syn. Ricker, 1963: i.1. in Illies, 1966: 325). Type in MCZ (\#27722), examined.

Atoperla ephyre: Illies, 1966: 325.

Perlinella ephyre: Zwick, 1971: 319; Zwick, 1973: 279; Hitchcock, 1974: 164.

Male. Body length $7-11 \mathrm{~mm}$; forewing length 7-10 mm. General color brown to dark brown. Head with 2 ocelli, occasionally with faint impression at location of anterior ocellus; dorsum of head with dark pigmentation usually extending to anterior margin of frons (Fig. 2), but sometimes limited to ocellar region (Fig. 3). Prothorax usually without middorsal stripe (Fig. 2), but if no dark clypeal coloration, prothorax often with pale middorsal streak (Fig. 3). Paraprocts sclerotized, sharply pointed apex (Fig. 9) recurved over posterior margin of tergum 10 (Fig. 6). Aedeagal sclerites expanded ventrally into rounded lobe in distal $1 / 4$, serrated laterally along expanded lobe, terminating in sharp downturned darker hook on inner margin, resulting in claw-hammer shape in lateral aspect 

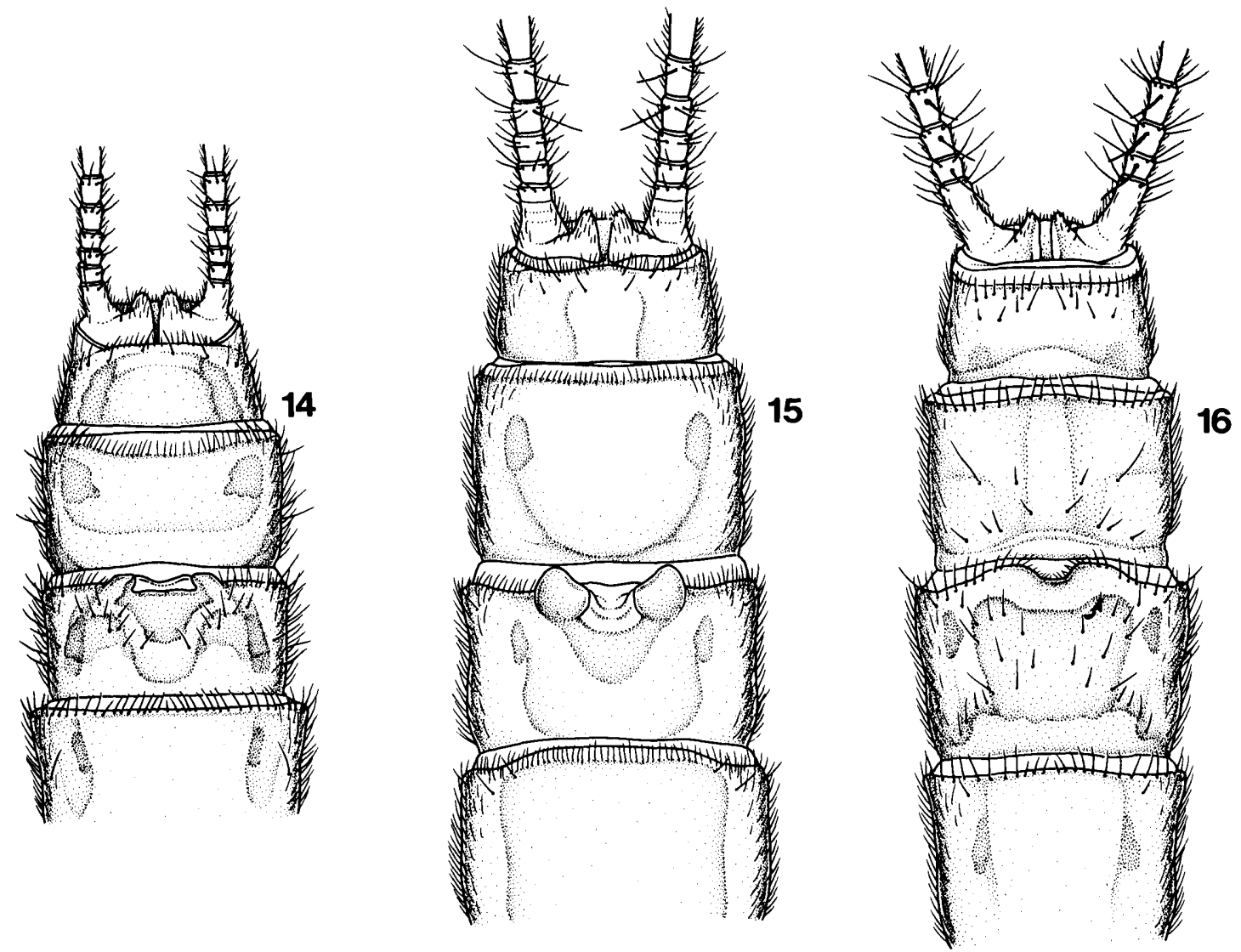

Fig. 14-16. Female terminalia, ventral view: (14) P. drymo, (15) P. ephyre, (16) P. zwicki.

(Fig. 12); spinules distributed over membranous sac apically,

Female. Body length 9-13 mm; forewing 10-14 $\mathrm{mm}$. Color similar to that of male (Fig. 2 and 3 ). Subgenital plate bilobed, lobes usually obliquely truncated, produced toward midline posteriorly, forming deep membranous notch (Fig. 15). Vagina with patches of golden brown spinulae. Spermathecum membranous, typically with 4 short accessory glands.

Egg. Outline oval, circular in cross section, surface smooth (Fig. 19). Collar stalked, umbrellalike tuberculate anchor plate stalked; micropyles near posterior pole just above subequatorial ridge (Fig. 19).

Nymph. Claassen (1931) and Frison (1935) described the nymph in detail. Body length $6-13 \mathrm{~mm}$. Body uniformly yellowish brown. Two ocelli. Subanal lobe gills small and inconspicuous (may be broken off).

Type Material. Ricker (1938) examined the holotype female and confirmed the usage proposed by Needham \& Claassen (1925) and Frison (1935). We examined the types of $P$. producta, a female specimen determined by Walsh as $P$. producta Walsh, and types of $P$. consors, but the type of $P$. fumipennis is no longer in existence (Frison 1935).
In agreement with Needham \& Claassen (1925) and Frison (1935), we consider $P$. fumipennis Walsh a synonym of $P$.ephyre, rather than Zwick's (1971) use of the name for "very dark specimens" from Florida. Walsh (1862) described Perla fumipennis from an adult male collected from Rock Island, Illinois. It differed from $P$. producta by "the anterior and posterior wings being distinctly and equally subfumose" and "head bright clay-yellow, the spot enclosing the ocelli black." Walsh (1863) further supplemented his original description with the following points: "head bright or obscure luteous [brownish-yellow]" and "wings equally tinged with fuscous [dark brown]." Conspicuously darker specimens matching Walsh's $(1862,1863)$ (fumose wings and unmarked frons) descriptions were examined from Illinois, Kansas, Missouri, South Carolina, and Virginia. The aedeagi of these specimens all have the sharp sclerotized hooks typical of all other $P$. ephyre populations examined throughout its geographical range. Frison (1935: 378) previously concluded: "upon the basis of comparisons of Illinois material with the original description and our intimate knowledge of the Illinois fauna which does not indicate the existence of another species closely allied to ephyre." Because the characters mentioned by Walsh in his original description fall 

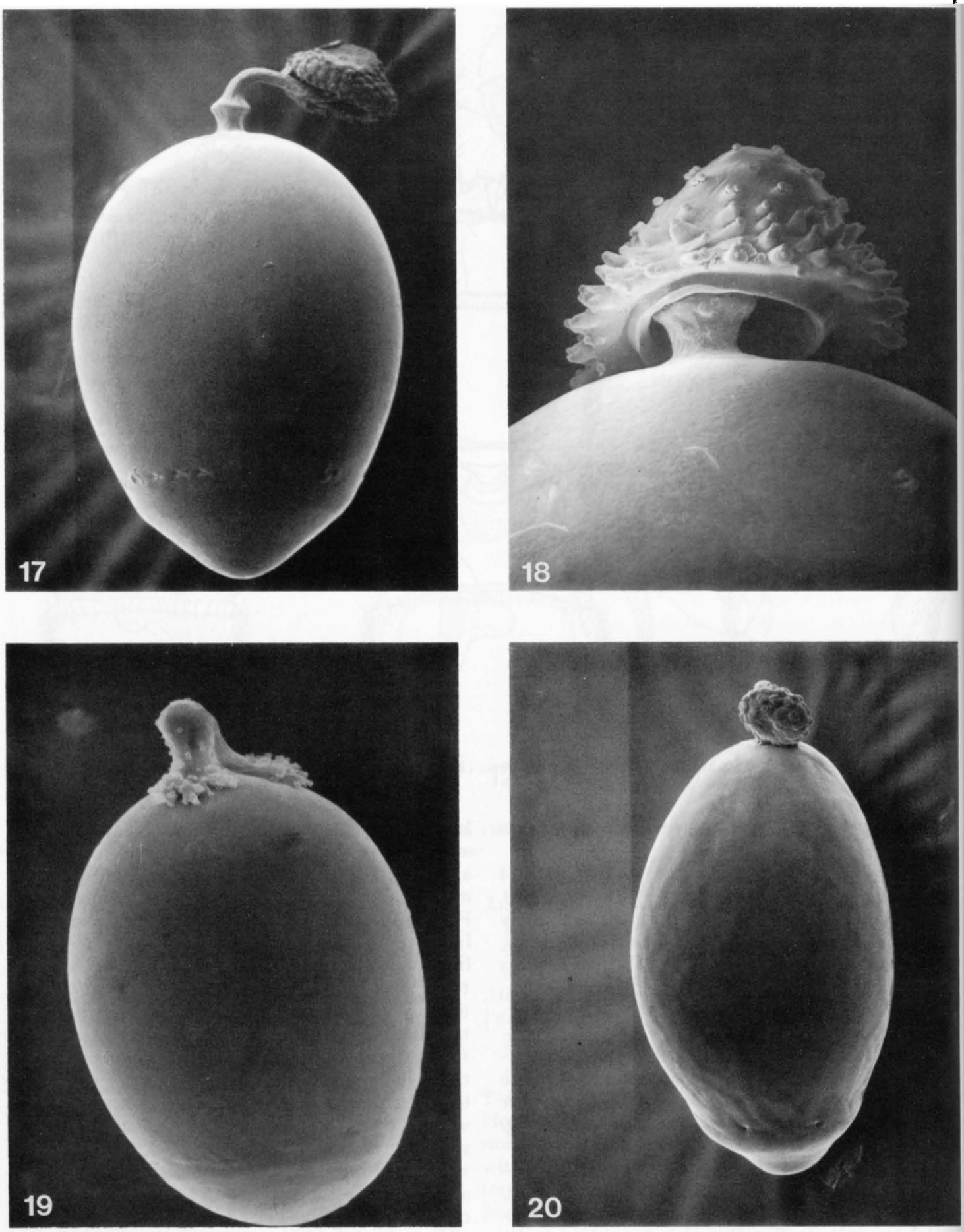

Fig. 17-20. Scanning electron photomicrographs of eggs: (17) P. drymo, 276×; (18) P. drymo, egg collar, $680 \times$; (19) P. ephyre, 312×; (20) P. zwicki, $230 \times$.

within the range of the color variation of this species, and on the basis of the above evidence, we synonymize $P$. fumipennis with $P$. ephyre.

Material Examined. Arkansas (1 \&) Washington Co.; Connecticut (3 ở, 1 i̊) Lorain Co., Tolland
Co.; Florida (75 ổ̂, 5 ९̊, 1 N) Okaloosa Co.; Georgia (3 §̊) Burke Co.; Illinois (5 ổ, 12 §̊, 4 N) Daviess Co., Ogle Co., Rock Island Co., Winnebago Co. Vermilion Co.; Indiana ( 2 ở, 2 오, $1 \mathrm{~N}$ ) Dubois Co.; Kansas (1 o) Cherokee Co.; Louisiana (1 \&, 2N) 


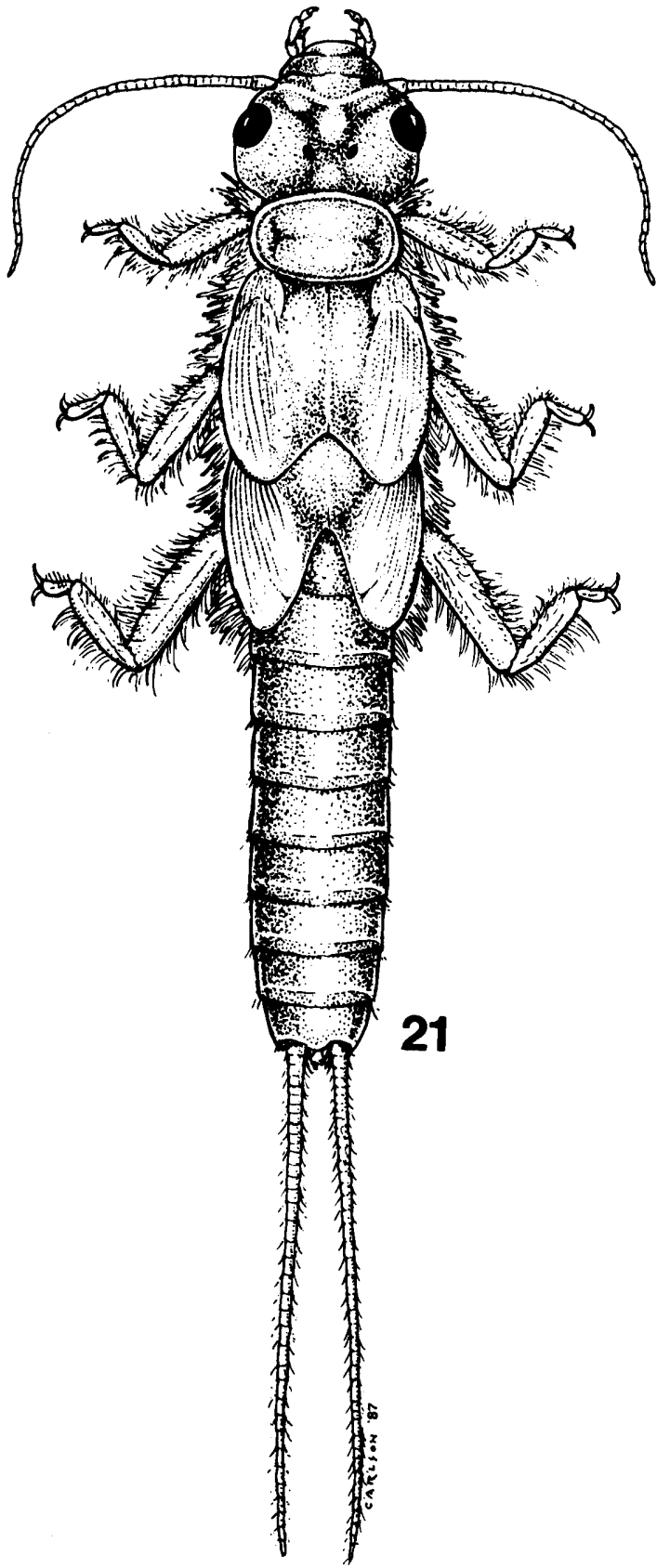

Fig. 21. Mature nymph habitus, P. zwicki.

Washington Parish; Maryland (2 \&ô, 1ㅇ) Plummers Island; Massachusetts (51 §ơ, $87 \AA q, 1 \mathrm{~N})$ Hampshire Co.; Maine (1 \&) Valley Grove; Minnesota (6 ố, 3

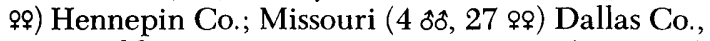
McDonald Co., Taney Co.; New Jersey (1 $\hat{\delta}, 2$ \&q) Gloucester Co., Ocean Co.; New York (3 \&ᄋ) Tompkins Co.; Ohio ( 1 ô) Franklin Co.; Oklahoma (3 ơd, 3 \&̊) Ottawa Co., Sequoyah Co.; Pennsylvania (2 ỡ, 5 ‡̊) Cumberland Co.; South Carolina (5 ở, 34 ¡̊) Aiken Co.; Tennessee (3 §ô, 34\%?) Marshall
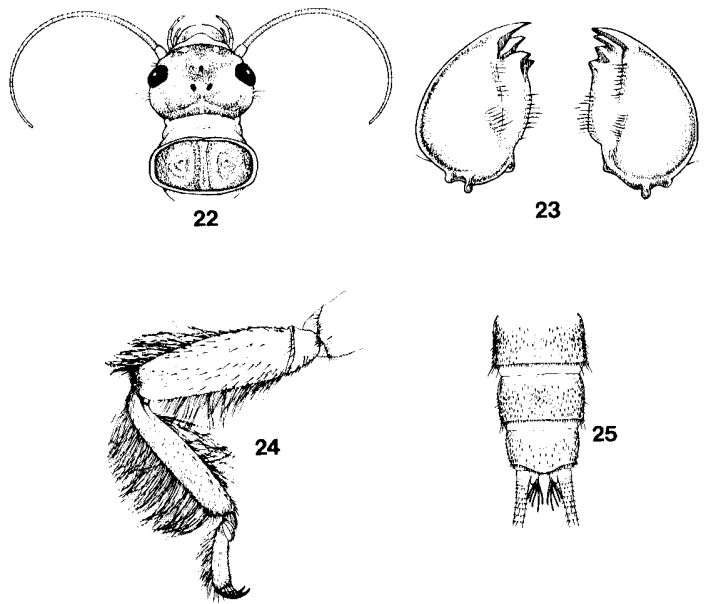

Fig. 22-25. (22) Nymph head and pronotum, $P$. drymo; (23) nymphal mandibles, $P$. drymo; (24) nymphal right front leg, $P$. drymo; (25) nymph terminalia, dorsal view, $P$. drymo.

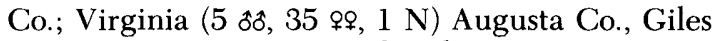
Co., Montgomery Co., Rockingham Co., Scott Co.; West Virginia ( 1 \%, 2 \%?, 1N) Greenbrier Co., Hampshire Co., Monroe Co.

Perlinella zwicki Kondratieff et al., n. sp.

Perlinella fumipennis: Zwick, 1971: 318. (nec Walsh).

Perlinella fumipennis: Zwick, 1973: 279 (nec Walsh); Hitchcock, 1974: 165; Stark \& Gaufin, 1976: 36; Stark \& Gaufin, 1979: 422.

Male. Body length 7-10 mm; forewing length 7-11 mm. General color usually dark brown to black. Head yellow except for dark pigmentation over ocellar region, 2 ocelli (Fig. 4). Prothorax without distinctive middorsal stripe (Fig. 4). Paraprocts sclerotized, with abrupt small hooklike apex (Fig. 10) curved over posterior margin of tergum 10 (Fig. 7). Aedeagus with lateral sclerites expanded in distal $1 / 3$, serrated (20-24 teeth) laterally along expanded lobe and terminating meso-apically in broad point (Fig. 13). Spinules generally distributed over membranous sac apically.

Female. Body length $8-12 \mathrm{~mm}$; forewing length 8-12 mm. Color similar to that of male. Subgenital plate broadly bilobed, slightly produced with shallow notch (Fig. 16). Vagina with patches of golden brown spinulae. Spermathecum membranous, typically bearing 6 slender accessory glands apically.

Egg. Outline elongate-oval, circular in cross section. Collar stalked and umbrellalike anchor plate stalked, tubercules large, rounded (Fig. 20). Micropyles near posterior pole, above raised subequatorial ridge.

Nymph. Body length 8-10 mm. Uniformly dark brown. Head slightly wider than pronotum, with pale areas; eyes in line with lateral ocelli; anterior ocellus absent (Fig. 21). Mandibles each with 4 
teeth; right mandible with teeth $3 / 4$ subparallel (as Fig. 23). Legs with a dorsal and a ventral fringe of long silky hairs (Fig. 21). Subanal lobe gills small, inconspicuous (may be broken off).

Type Material. HOLOTYPE ô, ALLOTYPE South Carolina: Aiken Co., Upper Three Runs Creek, Savannah River Plant (SRP), Road C, 3 June 1984, B. C. Kondratieff. PARATYPES (all collected by B. C. Kondratieff except where indicated): Same as holotype, 1 o, 4 ㅇ. South Carolina: Aiken Co., Upper Three Runs Creek, SRP, Road C, 5 May

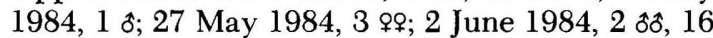

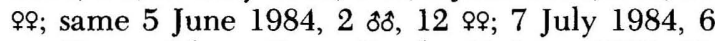
ㅇ․ Upper Three Runs Creek, 28 June 1977, D. Herlong and S. Prichard, 2 ơ̂, 2 ¡̊ (R.W.B.); Aiken Co., Tinker Creek, SRP Road B-1, 1 June 1977, D. Herlong and S. Prichard, 3 ઠ̂̉, 57 ¡̊ (R.F.K.); 13 June 1977, 1 ô, 35 §̊ (R.W.B.); Barnwell Co., Four Mile Creek, SRP, Road A-7, 5 June 1985, 1 ô, 1 \&. Alabama: Escambia Co., Atmore, 5 June 1962, F. S. Blanton, $1 \delta$, (R.W.B.); Perdido Creek, U.S. HWY 31, 3 June 1940, 2 \&, L. Berner (I.N.H.S.). Florida: Okaloosa Co., Blackwater River, Bryant Bridge, 2.5 mi W of Holt, W. Peters et al., 1 o (R.W.B.); Shoal River, HWY 90, 26 May 1973. A. R. Gaufin (R.W.B.), 1 o, 1 \&. Mississippi: Stone Co., 18-19 May 1978, 5 ơô, 3 §̊, P. P. Lago (U.M.).

The nymph is described from a reared male and 1 mature female nymph collected from Upper Three Runs Creek, South Carolina.

The holotype, allotype, and paratypes will be deposited in the U.S. National Museum of Natural History. Other paratypes will be deposited in the collections of the Department of Entomology, Virginia Polytechnic Institute and State University; Department of Biological Sciences, North Texas State University; Monte L. Bean Museum, Brigham Young University; R. F. Kirchner and B. P. Stark collections.

Etymology. The specific name honors Peter Zwick, who first recognized this species.

Remarks. This is the species which Zwick (1971) determined as being distinct from $P$. ephyre. Most of the specimens examined during the study were as described by Zwick (1971). However, in a series from South Carolina, there were relatively paler specimens (wings subhyaline, body color brown) whose aedeagi lacked the sharp downturned sclerotized hook; the subgenital plate was also typical of $P$. zwicki (Fig. 13 and 16). The color intensity of the body and wing pigmentation of this species varies as in all Perlinella.

Perlinella zwicki is a southeastern Coastal Plain stonefly, frequently inhabiting blackwater streams with shifting-sand substrata. Most of the adults were collected by light traps. Morse et al. (1980) described Upper Three Runs Creek, the type locality.

\section{Drumming}

The calls of male $P$. drymo (Fig. 26) and $P$. ephyre (Fig. 27) have identical patterns of 3 beats
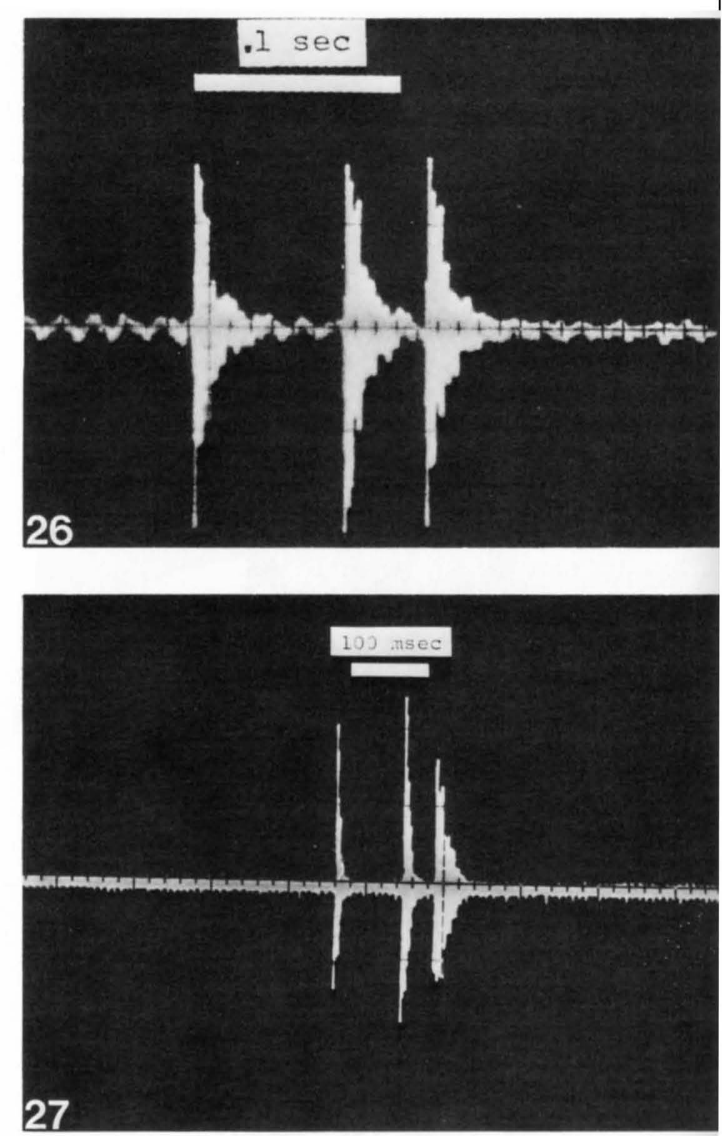

Fig. 26 and 27. Male drumming calls: (26) P. drymo (after Stewart \& Zeigler 1984b); (27) P. ephyre.

but different beat intervals. The second interval spacing is similar in both species $(38.0 \pm 3 \mathrm{msec}$ and $40.0 \pm 0.1 \mathrm{msec}$, respectively), but the spacing of the first interval is substantially shorter in $P$. drymo $(67.0 \pm 4 \mathrm{msec})$ than in $P$. ephyre $(89.5 \pm$ $0.8 \mathrm{msec}$ ). We have also preliminary unpublished data for the related Hansonoperla appalachia, in which the male call also has 3 beats, but with the first and second intervals much longer, at about 80 and $850 \mathrm{msec}$, respectively, than in the Perlinella species. Therefore, specificity of the drumming behavior in these three species in two closely related genera lies only in the different beat intervals of male calls. Such similarity in number of beats has not been found in congeners of any other North American genus where behavior of several species is known (e.g., Taeniopteryx, Pteronarcys, Isoperla, Acroneuria). This suggests that degree of change or evolution of drumming varies among species in different genera, and that in Perlinella and Hansonoperla, change has been slower than morphological change.

It is not uncommon to collect all three species of Perlinella from the same stream in many areas of the southeastern United States. In these areas, $P$. drymo usually emerges from late February to 